Article

\title{
Employees' Perceptions of Training and Sustainability of Human Resource
}

\author{
Chia-Wen Lee ${ }^{1}$, Weidong $\mathrm{Wu}^{2, *}$ and Cheng-Fu Yang ${ }^{3, *}$ \\ 1 College of Humanities and Communications, Yango University, Fuzhou 350015, China \\ 2 College of Humanities, Jinan University, Zhuhai 519070, China \\ 3 Department of Chemical and Materials Engineering, National University of Kaohsiung, \\ Kaohsiung 811, Taiwan \\ * Correspondence: wd.wu@jnu.edu.cn (W.W.); cfyang@nuk.edu.tw (C.-F.Y.)
}

Received: 17 June 2019; Accepted: 21 August 2019; Published: 26 August 2019

check for updates

\begin{abstract}
Employees' perceptions of training are one of the keys to sustainability in human resources. Based on data from a survey conducted in Shanghai and nine other large cities, this study explores employees' perceptions of training and tries to identify what factors influence their perceptions. The results show that employees do not attach enough value to vocational training. Urban registration, higher education, and management positions correspond with higher valuation of training, but length of service has a negative effect on their valuation. The differences between urban households and rural households, the social distinction between basic education and vocational education paths, and the increases of frequency, time, and importance of the interactions between personal and work places may play an important role in these phenomena and have impacts on the sustainable development of human resources in China.
\end{abstract}

Keywords: life course; social institute; perception of training; sustainability

\section{Introduction}

Sustainable human resource management in an organization ought to help employees achieve sustainable performance [1]. As vocational training is the main way for employees to improve their employment skills, such training should attract and retain employees' interest. The basic principle of symbolic interactionism holds that individuals take actions that correspond to meanings they assign to particular events or objects [2]. The Thomas theorem proposes that an individual's subjective interpretation directly affects their behaviors [3]. Studies have discovered that employees with a greater understanding of the value of vocational training participate more actively in the vocational training their workplace provides and work harder [4]. Conversely, employees with an inadequate understanding of the importance of vocational training are unwilling both to invest in training and to accept lower wages resulting from employers paying for training [5]. In this context, employees' perceptions of training play a crucial role in the human resource sustainability of an organization.

Employees' perceptions of vocational training refer to employee attitude toward, knowledge of, and emphasis on vocational training. The training concepts of employees come from the process of socialization, which is resulted from the individual acceptance of socialization, in the drive of social consciousness. As social institutes for socialization, families, schools, peer-groups, mass media, and work places can influence individual perceptions. According to the differential association theory, his/her behavior is dependent on how long and how importance of the experience an individual interacts with different social institutes [6]. Life course theory holds that a life course is a sequence of socially defined events and roles that the individual enacts over time [7]. The life course is divided into stages that correspond to different social institutions; control codes at each stage affect the development 
of the individual's life course, encouraging them to conform to society at a certain level [8]. Deviation from prescribed social paths often detrimentally affects an individual's life course [9]. According to life course and differential association theories, the individual plays different roles and undergoes a variety of life events at different ages.Consequently, the frequency and duration of their interactions with different social institutes vary, as does their recognition of the importance of these social interactions. For example, in the school education stage, the frequency and duration of interactions between individuals and schools increase, and individuals' concepts about learning and training are for the most part shaped during this stage. After employment commences, the influence of the work unit on the individual's conception of training is likely to rise. However, if individuals deviate from the usual social paths-for example, by not gaining skills education and training-they may be unable to fully grasp the importance of vocational training, which may affect their understanding and appreciation of this in the workplace.

In this study, we investigated how much importance employees placed on vocational training and what factors affected this importance, using a questionnaire administered to employees in 10 large Chinese cities. Certain specific features of the Chinese context make it a vital arena for exploring employees' perceptions of vocational training, the key one being the number of Chinese rural migrant workers, which reached 288 million in 2018. These workers comprise a rising proportion of the national workforce. When they arrive from rural areas, they are likely to have had little or no prior contact with vocational training and usually lack any direct understanding of it. The main contributions of this research are as follows:

(1) In the interest of increasing human resource sustainability in organizations, we used empirical analysis to determine the factors affecting the value employees place on vocational training. These factors can be targeted and controlled in a manner that effectively improves employees' perceptions about vocational training, leading them to be more pro-active about and participatory in vocational training and thereby enhancing their workplace skills. This will in turn help employees cope with the risk of structural unemployment in an era of industrial upgrading, which has crucial implications for the sustainable development of human resources in China.

(2) Life course theory has gathered considerable attention in recent years and has been applied to research related to employment, unemployment, poverty, and sex preference in rural labor transfer. While this theory is continually being developed and refined, differential association theory is relatively rarely applied. This study employs life course theory and differential association theory as its theoretical base to conduct an empirical analysis of employees' perceptions of vocational training; the study findings thus contribute to the development of both theories.

\section{Literature Review}

In recent years, many scholars have investigated the relationship between employment rate and human resource sustainability in China. It has been noted that vocational training has a significant positive impact on the employment quality of migrant laborers in terms of their income, employment stability, employment satisfaction, and labor insurance [10]. Compared with formal education, vocational training is more conducive to promoting regular employment, helping laborers achieve relatively stable employment, and preventing unemployment [11]. Vocational training improves the skill level of the labor force and has positive and important practical significance for stabilizing the labor market and reducing unemployment [12]. To boost human well-being, it is important to guarantee equal opportunities for employment between contemporaries as well as different generations [13]. Vocational training is a proven method of effectively achieving greater equality in employment opportunities and higher labor market sustainability [12,14].

Previous studies of sustainability development in China have measured the sustainability of economic and social development from the macro perspective of cities and regions, using unemployment rates as the reference data for social progresses, social distribution indexes [15-17], social stable abilities [18], human capitals [19], and labor forces for regional development [20]. Cheng and Long 
point out that increasing investment in education and improving the quality of the labor force can promote regional economic and social development and provide a talent system to guarantee sustainable regional and urban development [15]. Most previous studies have been carried out from a macro perspective and have not discussed in depth the micro/individual perspective. This study aims to address that gap by examining the perspectives of migrant workers on self-training and employment awareness.

Factors influencing employees' perceptions of vocational training are a crucial area for academic discussion [21]. Studies have suggested that lack of experience with vocational training in the early stages of an employees' career causes inadequate recognition of its importance and unwillingness to pay for participation in such training; perceived risks about investing in their own human capital discourage risk-averse employees from participating in vocational training [22]. In recent years, academics around the world have begun to pay attention to Chinese employees' perceptions of vocational training. Newman et al. surveyed 437 Chinese employees at five multinational firms operating in China's service industry and found that these employees' recognition of the value of vocational training did not increase their sense of belonging in their companies [23]. This may be because of the limited opportunities for promotion in multinational firms, the compulsory nature of vocational training for employees of such firms, and the difficulty of practicing and applying new skills.

Perception research is one of the main foci of study in Chinese academia. Research targets have gradually expanded from mate selection, career selection, and reproduction to perceptions about happiness, consumption, interests, and fairness. While theoretical analysis has been conducted on different perceptions, relevant empirical research has also progressed [24-26]. For example, one study used survey data from farmers to conduct logistic regression analysis of factors that influenced farmers' perceptions of raising children so they will be looked after in old age [25].

Discussion of employees' perceptions of vocational training remains extremely weak in the Chinese academic world, and examination at the empirical level is particularly scant. The few empirical studies that have been conducted focused predominantly on theoretical analysis of teachers' perceptions ofvocational training. The deep-rooted problem of teacher training in the middle and long term is no longer limited to technical or approach-related problems; teachers' perception that vocational training lags behind their skill development must be resolved, and this perception must be reconstructed from multiple perspectives, including views on teachers' rights and values [27]. Physical education teachers reach a plateau in their teaching skills, leading them to think they are competent at teaching; consequently, they have an inadequate understanding of the importance of vocational training [28]. Focusing on migrant workers, Dai and Liu carried out their research in six Chinese cities and found that migrant workers' positive perception of vocational training played a key role in their decision to take part in such training [29]. Han surveyed 376 migrant workers and found that those with more occupational skills or higher actual annual income attached more importance to vocational training [30]. The outcomes of existing studies form somewhat of a foundation for future research [27-41]. However, empirical studies are missing and urgently required.

\section{Research Method}

\subsection{Research Design}

Employees' perceptions of vocational training, a dimension of the individual social consciousness, is the individual's realization and value judgment for the objective things in society. This kind of value judgment is based on the individual's understanding of objective things at two levels: (1) whether the individual thinks objective things are important and worth pursuing; (2) the importance of this objective thing relative to other objective things. This second level, value judgment, is more important as it directly determines the individual's decision-making process when faced with difficult choices. What an individual chooses to do in the face of major decisions reflects their knowledge and value 
judgment about specific things. The present study analyzes employees' perceptions of vocational training by measuring their views on the relative importance of vocational training.

We designed a Likert-scale-based questionnaire to investigate the value employees place on vocational training. The questionnaire asked: "When seeking a job, which of the following factors are you most concerned about?" Eight major factors were listed: employment contract duration, vocational training, work content and location, working hours and vacations, salary, social insurance, employeesafety and occupational disease prevention, and employee benefits. The respondents rated these items on a 4-point Likert scale with the following anchors: 4 (extremely concerned), 3 (relatively concerned), 2 (not particularly concerned), and 1 (completely unconcerned). The level of employee emphasis was determined by calculating the proportion of employees who reported high concern for a factor. The factors were then ranked and compared according to their total scores. The scale was based on the context of a job search, a crucially important decision-making process for individuals. Hence, the level of concern about different factors in such a process is a good reflection of the importance the respondents placed on each factor and conveys theirperceptions and value judgment of vocational training.

As this study is structured around the work unit and life course of employees, the questionnaire design focused on the effect of the work unit on employees' perceptions of vocational training and concurrently analyzed the effects of school and family, two important social institutions in the socialization process that shapes each individual's perception of training. To characterize respondents' work units, five factors were included in the questionnaire: industry category, firm ownership, firm size, employee position, and working year. Industry category, firm ownership, and firm size are relevant to work units as factors in employee socialization. Position and working year are concerned with the individual's life experience. We also included items about school and family, including education level, household registration, gender, and marital status. Education level was included to gauge what social path the respondent had followed in this regard. Household registration was included because of the impact of family on respondents' socialization; it is possible that the region, village, or city from which a respondent came was a factor shaping their perceptions of vocational training. Gender and marital status indicated the individual's role in a family structure. Age data were also collected and incorporated into the analysis to better understand where the respondent was in the life course.

\subsection{Sample}

Cluster sampling was used in 10 cities, with investigators using the order "district, street, community, employee." Screening questions were included in the questionnaire, and a follow-up questionnaire was conducted to confirm the respondents' identities were confirmed. A total of 2000 questionnaires were distributed, and 1813 valid completed questionnaires were returned, yielding a valid return rate of $90.7 \%$. The respondents providing the valid questionnaires were from Shanghai (293), Shenzhen (300), Tianjin (300), Nanjing (195), Changsha (197), Chengdu (208), Wenzhou (105), Xiamen (100), Mianyang (104), and Changchun (108). The overall descriptive statistics for demographic characteristics were gender, age, household registration, marital status, education level, position, working year, industry category, firm size, and firm ownership, shown in Table 1.

Table 1. Descriptive statistics for demographic characteristics.

\begin{tabular}{cl}
\hline Variables & \multicolumn{1}{c}{ Index and Percentage } \\
\hline Gender & Male $60.3 \%$; Female $39.7 \%$ \\
\hline Age & 20 years or blow $10.1 \% ; 21-25$ years $45.9 \% ; 26-30$ years $22.2 \% ; 31-40$ years \\
& $15.4 \% ; 41$ years and above $6.4 \%$ \\
\hline Household registration & Rural areas $56.7 \%$; Urban areas $43.3 \%$ \\
\hline Marital status & Unmarried $66.4 \%$; Married $32.9 \%$; Divorced $0.7 \%$; Widowed $0.1 \%$ \\
\hline
\end{tabular}


Table 1. Cont.

\begin{tabular}{cl}
\hline Variables & \multicolumn{1}{c}{ Index and Percentage } \\
\hline \multirow{2}{*}{ Educational level } & $\begin{array}{l}\text { Junior high school or below 20.2\%; Senior high school 34.3\%; College 26.4\%; } \\
\text { Bachelor's degree or above 19.0\%; }\end{array}$ \\
\hline Position & $\begin{array}{l}\text { Management } 10.8 \% ; \text { Technology research } 11.6 \% ; \text { Marketing } 20.4 \% ; \\
\text { Administrative affairs 7.8\%; Production, Service 30.7\%; Others 18.7\% }\end{array}$ \\
\hline Working years & 5 years or less 74.3\%; 5-10 years 21.8\%; 10 years or more 3.9\% \\
\hline \multirow{2}{*}{ Industry category } & $\begin{array}{c}\text { Manufacturing 21.3\%; Construction 9.6\%; Wholesale and retail 14.1\%; } \\
\text { Catering and entertainment 12.7\%; Financial real estate 8.7\%; Home } \\
\text { economics training 7.2\%; Logistics 5.3\%; IT10.0\%; Others 11.0\% }\end{array}$ \\
\hline Firm size & 300 people or fewer 72.1\%; 301-1000 people 14.8\%; 1000 people or more 13.2\% \\
\hline Firm ownership & International 9.8\%; State-owned 18.2\%; Private 65.4\%; Others 6.6\% \\
\hline
\end{tabular}

\section{Results}

The survey results indicated that the employees were most concerned aboutsalary when searching for a job. They were not very concernedabout the vocational training offered, with this factor ranking second to last and receiving a score only slightly higher than the last item, which was employment contract duration. Notably, the score for vocational training was significantly lower than for the factor that ranked sixth, which wasemployeesafety and occupational disease prevention. More than $20 \%$ of the respondents reported being not particularly concerned about vocational training; see Table 2.

Table 2. Percentages of concerns during job search or labor contract signing.

\begin{tabular}{ccccccc}
\hline Variables & $\begin{array}{c}\text { Most } \\
\text { Concerned }\end{array}$ & $\begin{array}{c}\text { More } \\
\text { Concerned }\end{array}$ & $\begin{array}{c}\text { Less } \\
\text { Concerned }\end{array}$ & $\begin{array}{c}\text { Very } \\
\text { Indifferent }\end{array}$ & Mean & Ranking \\
\hline $\begin{array}{c}\text { Employment } \\
\text { contract duration }\end{array}$ & $30.4 \%$ & $44.1 \%$ & $23.6 \%$ & $1.8 \%$ & 3.029 & 8 \\
\hline $\begin{array}{c}\text { Content and place of work } \\
\text { Working hours }\end{array}$ & $38.5 \%$ & $49.0 \%$ & $11.7 \%$ & $0.8 \%$ & 3.252 & 5 \\
\hline $\begin{array}{c}\text { and vacation } \\
\text { Salary }\end{array}$ & $44.6 \%$ & $44.6 \%$ & $9.8 \%$ & $1.1 \%$ & 3.329 & 3 \\
\hline $\begin{array}{c}\text { Social Insurance } \\
\text { Employees' safety and } \\
\text { occupational disease } \\
\text { prevention }\end{array}$ & $46.4 \%$ & $32.5 \%$ & $4.7 \%$ & $0.6 \%$ & 3.563 & 1 \\
\hline Vocational training & $38.0 \%$ & $40.1 \%$ & $20.0 \%$ & $1.9 \%$ & 3.142 & 6 \\
\hline Welfare & $56.6 \%$ & $35.2 \%$ & $7.0 \%$ & $1.2 \%$ & 3.472 & 2 \\
\hline
\end{tabular}

To investigate and compare the effects of various factors on employees' perceptions of vocational training, this study constructed logistic models and conducted multivariate analyses. The dependent variable in the model was "concern about vocational training," and it was designed as a dichotomous variable. The independent variables in the model were industry, firm ownership, firm size, position, work experience, age, sex, marital status, household registration, and education level. Three models were constructed to incorporate different variable types. Specifically, Model 1 incorporated the family-related variables of household registration, sex, and marital status. Model 2 was the same as Model 1 but also incorporated a schooling-related variable (education level). Finally, Model 3 added the work-related variables of industry, firm ownership, firm size, position, work experience, and age. The results of the regression analysis are presented in Table 3. 
The analytical results for Model 3 indicated that when all variables were incorporated, industry, firm ownership, firm size, sex, age, and marital status were not significantly correlated with employee concern about vocational training, whereas household registration, education level, work experience, and position were significantly correlated. Further, the results of the multi-collinearity test indicated that the multi-collinearity of each independent variable in the regression equation was not severe, so the model was highly stable.

Table 3. Logistic models of training perceptions.

\begin{tabular}{|c|c|c|c|c|c|c|}
\hline \multirow{2}{*}{ Variables } & \multicolumn{2}{|c|}{ Model 1} & \multicolumn{2}{|c|}{ Model 2} & \multicolumn{2}{|c|}{ Model 3} \\
\hline & B & OR & B & OR & B & OR \\
\hline \multicolumn{7}{|c|}{ Household registration (rural as reference) } \\
\hline Urban & $0.530^{* * *}$ & 1.699 & $0.384^{* * *}$ & 1.468 & $0.391^{* * *}$ & 1.478 \\
\hline \multicolumn{7}{|c|}{$\begin{array}{c}\text { Education level (junior high or below } \\
\text { as reference) }\end{array}$} \\
\hline Senior & & & -0.015 & 0.985 & -0.068 & 0.934 \\
\hline College & & & $0.538^{* *}$ & 1.713 & $0.441^{* *}$ & 1.555 \\
\hline Bachelor or above & & & $0.539 * *$ & 1.714 & 0.361 & 1.434 \\
\hline \multicolumn{7}{|c|}{ Position (management as reference) } \\
\hline Technology \& research & & & & & -0.483 & 0.617 \\
\hline Marketing & & & & & -0.305 & 0.737 \\
\hline Administrative affairs & & & & & $-0.547 *$ & 0.579 \\
\hline Production \&service & & & & & $-0.560 * *$ & 0.571 \\
\hline Others & & & & & $-0.467^{*}$ & 0.627 \\
\hline \multicolumn{7}{|c|}{ Working years ( 5 years below as reference) } \\
\hline $5-10$ years & & & & & $-0.470 * * *$ & 0.625 \\
\hline 10 years above & & & & & -0.541 & 0.582 \\
\hline Constant & $1.551^{* * *}$ & 4.717 & $1.145^{* * *}$ & 3.142 & $1.785^{* * *}$ & 5.959 \\
\hline $\mathrm{R}^{2}$ & 0.033 & & 0.051 & & 0.070 & \\
\hline
\end{tabular}

In Model 3, the regression coefficient for employees with urban household registration was 0.391 . It was discovered that employees with urban household registration were 1.478 times more likely to value vocational training than their counterparts with rural household registration. Respondents with a bachelor's degree were $55.5 \%$ more likely to be concerned about vocational training than their counterparts with a junior high school diploma or lower education level. In terms of position, the respondents in management positions had higher awareness of the importance of vocational training than the respondents in either administrative or production and service positions. The proportions of respondents in these types of position who showed concern about vocational training were only $57.9 \%$ and $57.1 \%$, respectively, compared with the proportion in management positions. Finally, the proportions of employees with 5-10 years and more than 10 years of work experience who were concerned about vocational training were only $62.5 \%$ and $58.2 \%$ of the proportion of employees with less than 5 years of experience who showed such concern.

\section{Discussion}

Research on employees'perceptions of vocational training for sustainable human resource have paid attention for many years and yielded excellent results. However, most of these studies focus on the labor constraints of vocational training and the relationship economic development and employees' 
perceptions of training [31,32], but it is not completely applicable to the employees' perceptions of vocational training, in particular the research on the field in China is weak. Therefore, it is necessary to explore employees' perceptions of vocational training as China's industrial transformation and upgrading in globalization's new era.

In this study, junior high school, senior high school (including vocational high school), and higher education correspond to different social institutions and thus stratify the life course of individuals during their education. Individuals who completed only junior high school education did not advance to senior high school or institutions of higher education, which focus on vocational skill education. This cessation of education creates a gap between basic education and vocational education, generating an inadequate understanding of the importance of vocational training. Later in life, this can have unfavorable consequences, such as unemployment and poverty. Our results showed that the proportion of respondents with a junior high school diploma or lower education level concerned about vocational training was less than half that of respondents with a bachelor's degree. These results are congruent with Gao's research, which found a positive relationship between education and the perception of training [33]. In the existing nine-year framework of compulsory education in China, vocational skill education is generally provided at the upper secondary and higher education levels; vocational training at the primary education stage is available in only a few low-income areas. Thus, most individuals receive vocational education only after they have begun high school. Hence, most employees with a junior high school education or lower have not receive vocational training. Higher education helps to deepen people's understanding of vocational training.

Schools and work units may differ in their emphasis on vocational training.From the perspective of life course theory, graduation is a "turning point," representing the life transition from "student" to "employee." Upon undertaking the role of employee, an individual spends significant time in a work unit. The frequency and duration of individual-work unit interactions increase markedly over time, and these interactions have a strong effect on an individual's life and perception of training. During their employment in a work unit, an individual is likely to change specific perceptions they formed when they were younger and attending other social institutions, such as school. With respect to vocational training, this change may be due to the individual's experience of vocational training in the workplace, or the individual may be influenced by their work unit; the influence of the latter may be greater.If a work unit places strong emphasis on vocational training, that unit's employees are likely to place greater value on such training. Conversely, if a work unit places little emphasis on vocational training, employees' interest is likely to follow suit.

In our study, the respondents' work experience was negatively correlated with their valuing of vocational training, suggesting that after several years of work, employees place significantly less emphasis on vocational training. This is consistent with previous findings. $\mathrm{He}, \mathrm{Li}$, and $\mathrm{Li}$ pointed out that migrant workers become less aware of the importance of vocational training the longer they have been working [41]. Liu and Bao's study found that the total profit and human capital investment capacity of a business has no significant impact on employees' perceptions of vocational training; even if businesses are able to provide vocational training, it is mostly fundamental job-preparation information and safety training to meet urgent needs [34]. Xie's study reported that the goals of vocational training are to enhance the practical work skills of employees to meet the production needs of the business itself; little emphasis is placed on improving employees' theoretical knowledge level and overall quality [35]. Under a power imbalance existing in employment relationships between strong employers and weak employees, works units place little emphasis on vocational training, and the training provided is of limited help for employees' career development.This phenomenon is very common in China. Our results showed that the external characteristicsof workplace of industry category, firm ownership, and firm size have no significant effects on employees' perceptions of training. This may be a peculiarity of China's labor relations, the most labors lack the motivation for vocational training, there is no links with the external characteristics of workplace.Consequently, employees' interest in vocational training lessens the longer they work, which is not beneficial for overall human resource sustainability. 
By in-depth knowledge of life course theory, the role of being the individual undertakes will influence his and her lives. This study found that the employee's role affected their perceptions of training. Respondents in management positions had a greater understanding of the importance of vocational training, probably because their jobs involve human resource management, which deepens their knowledge of worker employability and layoffs. The daily responsibilities of those in administrative, production, and service positions are concentrated at the service level, which may limit these employees' understanding of the importance of vocational training. Notably, however, family, gender, and marital status were not found to be significantly correlated with employees' perceptions of training. One possible reason is that families in urban areas no longer participate at the production level, so individuals may lack direct links to the concept of vocational training. Cheng and Long suggest that educational input can effectively improve the quality of human resources and promote the sustainable development of the economy and society [15]. These effects not only benefit individuals but also reduce crime rates and increase voluntarism and charitable donations as increasing human capital [19]. Nowadays, the citizens of most cities in China have a low average level of education and a high marginal benefit from educational input. To achieve sustainable human resource development, more efforts should be made to invest in employee training, to continuously improve the quality of labor force and the efficiency of human resources management, and to provide social guarantee systems.

\section{Conclusions and Limitations}

This study employed a questionnaire in 10 cities, including Shanghai, Mianyang, and Changchun, to investigate employees' valuation of vocational training and the factors affecting their valuation. The main research conclusions are as follows. (1) Vocational training was ranked second to last among the eight factors of concern to employees in a job search. The respondents were more concerned about salary and employee benefits and placed little emphasis on vocational training. (2) Household registration, education level, work experience, and position significantly influenced the respondents' attitude toward vocational training. Those with an urban household registration, a higher education level, and a management-level position placed more emphasis on vocational training. However, employees' valuation of vocational training decreased as their work experience increased. (3) A gap existed between rural and urban households, a phenomenon that may have two causes: the difference between rural and urban dwellers' basic education and vocational education levels, and the increase in the frequency, time, and importance of an individual's interaction with their work unit after employment.

The key implications of this research for practice are to inform decisions about achieving greater human resource sustainability in China. Vocational training is a crucial tool in sustainable human resource development, just as important as school education. Such training effectively improves employees' production skills, increasing not only their wages but also their businesses' productivity [34]. China's industrial structure is currently being upgraded, and the demand for labor skills is gradually shifting from physical to technical abilities. If employees fail to make corresponding changes through vocational training, a large structural supply-demand imbalance may occur in the labor market. This could lead to widespread unemployment and unsustainable changes in the country's human resources [35].

Currently, work units have limited understandings of human resource development. Proactive vocational training for employees is particularly important in these circumstances, but numerous employees are insufficiently aware of the importance of training; this situation needs to change quickly. The mass media, an influential social institution, should more strongly emphasize the importance of vocational training, particularly for rural migrants, lower-educated individuals, and sales employees. This would instill in employees the necessary understanding of the importance of vocational training and create a greater demand for vocational training on the part of employees, who will then actively and proactively participate in vocational training and improve its effectiveness. In addition, through the implementation of relevant policies and regulations, work units should be encouraged to respond 
more proactively to employees' training needs. Businesses should consider the problem of vocational training from a mutually beneficial perspective-the development of the work unit and of its employees. Companies should provide more vocational training opportunities and support to employees, thereby promoting sustainable human resource development.

With respect to theoretical implications, this research helps to broaden the applied fields of life course theory and differential association theory. By using these theories to analysis Chinese employees' perceptions of training, this study supports the application of these two theories in the Chinese context when analyzing perceptions of vocational training, especially among migrant workers from the countryside. One of the key features of the Chinese context is that a very large proportion of employees are rural-to-urban migrant workers. They grew up in rural families, social units with little or no understanding of vocational training. Life course theory and differential association theory provide further insight into the study of this group of workers in China.

This study has two major limitations that could be addressed in future research. First, the data are from a survey carried out in 10 cities. More data from other geographical regions are needed to advance the understanding of employees' perceptions of vocational training. Second, this study used a 4-point Likert scale for measuring the perceptions of training. Future studies could design a scale with more options to offer more insight into respondents' perceptions.

Author Contributions: Conceptualization, methodology, and data analysis, C.-F.Y., C.-W.L. and W.W.; writing-original draft preparation, C.-W.L. and W.W.; writing-review and editing, C.-F.Y. and C.-W.L.

Funding: This work was supported by projects under No. MOST 108-2221-E-390-005, MOST 108-2622-E-390-002 -CC3 and by "the Fundamental Research Funds for the Central Universities" (15JNQM017).

Acknowledgments: This manuscript was translated into English by Wallace. Financial support from the NSFC project titled; "Fabrication of high efficiency ammonia gas.

Conflicts of Interest: The authors declare no conflict of interest.

\section{References}

1. Li, S.L.; Sun, F.; Li, M. Sustainable human resource management nurtures change-oriented employees: Relationship between high-commitment work systems and employees' taking charge behaviors. Sustainability 2019, 11, 3550. [CrossRef]

2. Blumer, H. Society as Symbolic Interaction. Human Behavior and Social Process. In Human Behavior and Social Processes; An Interactionist Approach; Rose, A., Ed.; Houghton Mifflin: Boston, MA, USA, 1962.

3. Thomas, W.I.; Thomas, D.S. The Child in America: Behavior Problems and Programs; Knopf: New York, NY, USA, 1928.

4. Ahmad, K.Z.; Bakar, R.A. The association between training and organizational commitment among white collar workers in Malaysia. Int. J. Train. Dev. 2003, 7, 166-185. [CrossRef]

5. Ewart, K. Market failure and public policy on training: Some reasons for caution. Dev. Learn. Organ. 2006, 20,7-9.

6. Sutherland, E. Principles of Criminology, 4th ed.; J.B. Lippincott: Philadelphia, PA, USA, 1947.

7. Elder, G.H., Jr. The Life Course and Human Development. In Handbook of Child Psychology, Vol. 1: Theoretical Models of Human Development, 5th ed.; Lerner, R.M., Ed.; Wiley: New York, NY, USA, 1998.

8. Sameroff, A.J.; Suomi, S. Primates and persons: A Comparative Developmental Understanding of Social Organization. In Cambridge Studies in Social and Emotional Development. Developmental Science; Cairns, R.B., Elder, G.H., Costello, E.J., Eds.; Cambridge University Press: New York, NY, USA, 1996.

9. Bao, L.P. An analysis of the time view of life course theory. Sociol. Res. 2005, 4, 120-133. Available online: www.cnki.com.cn/Article/CJFDTOTAL-SHXJ200504004.htm (accessed on 11 June 2018).

10. Liu, X.; Wu, Z.M. Study on the vocational training demand and employment quality enhancement countermeasures of rural migrant workers in the process of new urbanization. Vocat. Tech. Educ. 2016, 34, $52-56$.

11. Wang, J. Formal education or skill training: Which investment in human capital is more beneficial to formal employment of migrant workers? China Rural Surv. 2017, 1, 113-126. 
12. Chen, L.F. Skill loss, learning by working and the persistence of unemployment. J. Guizhou Univ. Financ. Econ. 2017, 3, 1-14.

13. OECD. Measuring Sustainable Development; United Nations: New York, NY, USA, 2008.

14. Jia, M.; Zhang, X.L.; Nie, S.P. Theoretical premise and model building of reemployment skills training for surplus workers in overcapacity fields. Econ. Probl. 2018, 10, 78-84.

15. Cheng, G.B.; Long, W. Urban sustainable development capability in the Silk Road economic belt and its influencing factors-An empirical test based on the super-efficiency DEA-Panel Tobit Model. East. China Econ. Manag. 2017, 31, 35-43.

16. Zhang, W.; Duan, X.J.; Zhang, W.Y. Evaluation and evolution of sustainable devekopment in Yangtze River Delta. Resour. Environ. Yangtze Basin 2013, 22, 1243-1249.

17. Lu, C.Y.; Zhang, L.; Xue, B.; Zhang, Z.L.; Li, H.G.; Qui, C.P. Study on spatial-temporal comprehensive measurement of regional sustainable development in Liaoning Province. Econ. Geogr. 2015, 35, 32-39.

18. Guo, S.F.; Ma, Y.H. Comprehensive evaluation for sustainable development capacity of resource- based region. China Popul. Resour. Environ. 2017, 27, 72-79.

19. Wang, P. Is sustainable development measurable? Introduction to the United Nations handbook on sustainable development measurement. China Stat. 2014, 7, 26-27.

20. Zhang, J.Q.; Zhang, L.; Wang, S. Study on regional sustainable development efficiency measurement and influencing factors: Based on DPSIR-DEA Model. China Popul. Resour. Environ. 2017, 27, 1-9.

21. Barron, J.M.; Berger, M.C.; Black, D.A. Do workers pay for on-the-job training? J. Hum. Resour. 1999, 34, 235-252. [CrossRef]

22. Stevens, M. Human capital theory and UK vocational training policy. Oxf. Re. Econ. Policy. 1999, 15, 16-32. [CrossRef]

23. Newman, A.; Thanacoody, R.; Hui, W. The impact of employee perceptions of training on organizational commitment and turnover intentions: A study of multinationals in the Chinese service sector. Intern. J. Hum. Resour. Manag. 2011, 22, 1765-1787. [CrossRef]

24. Guo, J.P.; Chen, X.J. Investigation and analysis of consumption culture and the change of Guangdong's lifestyle: An empirical study of concepts. Guangdong Soc. Sci. 2013, 3, 185-195.

25. Ye, N. An empirical study on farmers' concept of raising children and preventing aging. N. W. Popul. 2012, 5, 24-28.

26. Zhang, G.; Wilking, J.R.; Yu, Z. Farmers' equity concept in China: An empirical study based on the election survey of village committees. Sociol. Res. 2010, 1, 64-84.

27. Li, J.Y. On the view of teacher training from a multidimensional perspective. Contem. Edu. Cul. 2009, 2, 69-73.

28. Pan, J.F.; Chen, Y.F.; Zhou, Z.Y. Views on the training of physical education teachers in the new era. J. Beijing Instit. Edu. 2010, 1, 39-41.

29. Xie, T.; Chen, T.J. Human capital, willing perception and rural technology training. Rural Econ. Sci. Tech. 2018, 1, 38-42.

30. Dai, F.; Liu, Q. Cognitive inertia and path dependence of migrant workers in vocational training. Dongyue Tribun. 2013, 1, 155-159.

31. Han, J. An empirical research of new generation peasant-worker's consumer willingness for vocational training: Study from sub-class, career expectation and consumption cognition. Res. Educ. Dev. 2017, 5, 53-58.

32. Hu, J.W.; Yin, W.Q.; Zhao, Y.K.; Guo, H.W.; Huang, D.M.; Sun, K.; Chen, Z.M.; Hu, S.L. Analyzing the cognition, willingness and demand on general medical training of rural doctors in Shandong Province. Chin. Health Serv. Manag. 2019, 1,43-45. Available online: http://d.old.wanfangdata.com.cn/Periodical/zgwssygl201901013 (accessed on 4 July 2019).

33. Gao, S. Factor influencing farmer's decision of attend technical training: Based on investigation of 1040 households in Hunan Province. J. Hunan Agric. Univ. 2011, 4, 21-26.

34. Liu, B.; Tao, H.Q. Empirical analysis of the impact of demographic characteristics and labor relations on vocational training. Popul. Sci. China. 2008, 6, 56-62.

35. Xie, X.Q. Investigation and analysis of vocational training investment. Financ. Res. 2009, 9, 45-46.

36. Becker, G.S. Human Capital: A Theoretical and Empirical Analysis, 2nd ed.; Columbia University Press: New York, NY, USA, 1975. 
37. Ding, Y.X.; Xu, Y.H.; Li, J.Z. The determinants of work-related training for migrant workers in China. Popul. J. 2011, 3, pp. 29-35. Available online: http:/www.cnki.com.cn/Article/CJFDTOTAL-LCYB201201025.htm (accessed on 20 April 2018).

38. Liu, T.; Shen, H.; Chau, K.Y.; Wang, X. Measuring scale development and validation of female employees' Career expectations in Mainland China. Sustainability 2019, 11, 2932. [CrossRef]

39. Lorincová, S.; Štarcho`n, P.; Weberová, D.; Hitka, M.; Lipoldová, M. Employee motivation as a tool to achieve sustainability of business processes. Sustainability 2019, 11, 3509. [CrossRef]

40. Yi, L.; Uddin, M.A.; Das, A.K.; Mahmood, M.; Sohel, S.M. Do transformational leaders engage employees in sustainable innovative work behavior? Perspective from a developing country. Sustainability 2019, 11, 2485. [CrossRef]

41. He, T.T.; Li, R.; Li, X.Q. Awareness and needs of specialist nurse training among nurses working in A-grade tertiary hospitals. J. Nurs. Sci. 2018, 19, 1-4.

(C) 2019 by the authors. Licensee MDPI, Basel, Switzerland. This article is an open access article distributed under the terms and conditions of the Creative Commons Attribution (CC BY) license (http://creativecommons.org/licenses/by/4.0/). 